\title{
Gender as Determinant of Students Performance in Mathematics Periodic Tests and Terminal Examination in Federal Capital Territory Secondary Schools in Nigeria
}

\author{
Oloda Festus Sunday Smart (Ph.D)* Ojo Solomon Gboyega (Ph.D) \\ National Mathematical Centre, Sheda - Kwali, Abuja. Nigeria
}

\begin{abstract}
The purpose of this study was to investigate the influence of students' gender on their performances in mathematics periodic tests and terminal examination. The aim was to determine the contributions of students' gender to performance of students in mathematics periodic tests and terminal examination. The study adopted an ex-post facto research design in which the researcher does not have direct control on the independent variables, since the manifestation had already occurred. It involves the collection of existing data. The target population for the study consisted of Junior Secondary School II (JSS II) students in Abaji Area Council of Federal Capital Territory, Abuja. 200 students were drawn from five (5) public schools through a multistage sampling technique. The researchers made personal contact with all the selected schools and collected the following items:

i. Copies of the three continuous assessments in mathematics of $2^{\text {nd }}$ term 2020/2021 academic session.

ii. The copy of terminal examination mathematics results of $2^{\text {nd }}$ term2020/2021 academic session.

iii. The sex of the selected students.

The result revealed that there was significant difference between the academic performance of male and female students in mathematics periodic Test $1(\mathrm{t}=3.386, \mathrm{P}<0.05)$, Test $2(\mathrm{t}=2.445, \mathrm{P}<0.05)$, Test $3(\mathrm{t}=2.217, \mathrm{P}<$ $0.05)$, Test $4(\mathrm{t}=2.659, \mathrm{P}<0.05)$ and Terminal examination $(\mathrm{t}=3.791, \mathrm{P}<0.05)$ at 0.05 level of significance. This was statistically significant at 0.05 level. The study established that students' performance in mathematics periodic tests and terminal examination were affected by students' gender. The study recommended that teachers should be gender sensitive and accommodating by taking into consideration individual differences in students' rate of learning irrespective of gender.
\end{abstract}

Keywords: Gender, periodic tests, terminal examination, performance

DOI: $10.7176 / \mathrm{JEP} / 12-27-12$

Publication date:September $30^{\text {th }} 2021$

\section{Introduction}

Mathematics is the bedrock to which the technological development of any nation is hinged, thus, importance of mathematics for any nation aspiring for scientific and technological advancement cannot be over emphasized. Mathematics provides opportunity to inculcate permanent literacy and numeracy in an individual as well as laying a sound basis for scientific and reflective thinking. According to Adetula (2010) mathematics is the linchpin in the task of national capacity building in science and technology and therefore, any short comings in this subject constitute drawback to the achievement of science and technology objectives. Thus, education policy makers in Nigeria made mathematics a compulsory subject from primary through secondary school and candidates are expected to pass it as part of the basic requirements for tertiary education. Also, a credit pass in mathematics among others is required to gain admission into Nigeria universities (Oloda \& Adebule, 2017). A credit pass in mathematics is also required as a prerequisite to the study of science courses in Nigerian colleges of education and polytechnic.

Despite the importance of mathematics, students still perform poorly at both internal and external examinations, which is a serious setback for secondary education in Nigeria. Thus, mathematics education in Nigeria is currently in a crisis state as evident in the poor performance of students in external examinations, this is supported by the performance of Nigeria candidates in general mathematics in the West African Secondary School Certificate Examination (WASSCE) from 2009 to 2016 which showed that the percentage of students that passed mathematics at credit level was between 43\% and 54\% except a little improvement recorded in 2016 where the percentage was $61.97 \%$ (Source: West African Examination Council, Yaba, Lagos). According to (Karau, 2006), the reason for the students' poor achievement in mathematics from year to year has been ascribed to several variables ranging from the learners themselves, teachers, textbooks, curricular among others.

Poor performances in mathematics have continued to be stumbling blocks in the realization of the educational desire of many candidates. Consequently and in line with government reform in education, Nigeria Educational Research and Development Council (NERDC) was directed in 2005 by the National Council on Education (NCE) to review and re-align the existing curriculum in mathematics to meet the target of the reform in the context of National Economic Empowerment and Development Strategies (NEEDS) and Millennium Development Goals (MDG). In the light of the above, the Senior Secondary School Mathematics Curriculum has 
some topics added to the existing ones. These are introductory topics in: Calculus (Differentiation and Integration), Coordinate geometry, Matrices, Modular arithmetic, logical reasoning and Financial Mathematics (Annuity and Armotization).

The National Policy on Education in 1977 which was revised in 2004 recommended a new approach to assessment on learning outcomes after strong consideration of the effects of the one single examination for determining the success or failure of an individual student. The new approach is called continuous assessment which is considered to be a better replacement of the inherited mode of assessment. Yoloye (1984) and Oloda \& Awogbemi (2012), see continuous assessment as a mechanism whereby the final grading of a student in the cognitive, affective and psychomotor domain of behaviour takes into account in a systematic way of all his performance during a given period of schooling. Continuous assessment is a systematic process used by teachers to determine how well the instructional objectives have been achieved, the effectiveness of pedagogy of teaching and the strength and weaknesses of individual student. Periodic test is a component of continuous assessment.

It has been observed in literature that gender disparity in mathematics education in terms of participation and performance is a problem. According to Ajayi and Ighoroje (2000), Faleye and Ojerinde, (2006), registration in science and related courses at the nations higher institutions is rapidly declining particularly for female students and some other "disadvantaged" groups of examinees. Agwagah (2013) opined that there is still low participation and poor performance of girls in mathematics, science and technology. According to Cronbach (1977), boys and girls do not differ much on ability measures. This is not unconnected with the fact that opportunities for development are much more the same until the school leaving age. Thus, psychologists and test experts/developers have tried to select test contents that would give neither sex an advantage nor favour any group over the other. However, there is general belief that male students seem to have advantages on their female counterparts in mathematics and mathematics related Examinations. Jahun and Momoh, (2001) found gender to be a significant factor in school mathematics.

There is general belief that male students seem to perform better than female students in mathematics and mathematics related subjects. According to Smith \& Walker (1988) and Popoola \& Ajani (2000) male students perform better than female students in mathematics.

\section{Objective of the Study}

The performance of students in senior secondary school mathematics has remained an issue of concern especially, to parents, teachers, students and other stakeholders in education. Students are often blamed for poor performance in mathematics while little attention is given to the fact that gender can affect students' achievement in mathematics. The problem of the study therefore is to determine the contributions of gender to students' performance in mathematics periodic tests and terminal examination.

\section{Research Question}

1. Is students' academic performance in mathematics periodic tests and terminal examination a function of gender of the student?

\section{Hypotheses}

1. There is no significant difference between the academic performance of male and female students in mathematics periodic tests and terminal examination.

2. There is no significant gender difference in the contribution of students' performance in mathematics Periodic Tests to their academic performance in Terminal Examination in Mathematics.

\section{Methodology}

The study adopted ex-post facto research design in which the researcher does not have direct control on the independent variables, since the manifestation had already occurred. It involves the collection of existing data. The population for the study consisted of Junior Secondary School II (JSS II) students in Abaji Area Council of Federal Capital Territory, Abuja. 200 students were drawn from five (5) public schools in Abaji Area Council through two-stage sampling technique. In the first stage, five schools were randomly selected using purposive sampling technique. At the second stage, 40 students (20 males and 20 females) were selected from each school through simple random sampling technique. Thus, a total of 200 students (100 males and 100 females) constituted the sample for the study. The researchers made personal contact with all the selected schools and collected the following items:

i. Copies of the four continuous assessments in mathematics of $2^{\text {nd }}$ term 2020/2021 academic session.

ii. The copy of terminal examination mathematics results of $2^{\text {nd }}$ term 2020/2021 academic session.

iii. The sex of the selected students. 


\section{RESULTS}

Results of data analysis obtained in the study are presented below according to the research question and corresponding hypotheses

\section{RESEARCH QUESTION 1}

1. Is students' academic performance in mathematics periodic tests and terminal examination a function of gender of the student?

Table 1: Descriptive Analysis of students' academic performance in mathematics periodic tests and terminal examination by gender

\begin{tabular}{|c|c|c|c|c|c|c|c|c|c|c|c|}
\hline \multirow[b]{2}{*}{ Gender } & \multirow[b]{2}{*}{$\mathrm{N}$} & \multicolumn{2}{|l|}{ Test 1} & \multicolumn{2}{|l|}{ Test 2} & \multicolumn{2}{|l|}{ Test 3} & \multicolumn{2}{|c|}{ Test 4} & \multicolumn{2}{|c|}{ Examination } \\
\hline & & Mean & SD & Mean & SD & Mean & $\mathrm{SD}$ & Mean & SD & Mean & $\mathrm{SD}$ \\
\hline Male & 100 & 5.02 & 1.28 & 5.00 & 1.19 & 4.98 & 1.26 & 4.88 & 1.33 & 53.98 & 11.96 \\
\hline Female & 100 & 4.46 & 1.21 & 4.56 & 1.35 & 4.58 & 1.29 & 4.40 & 1.22 & 47.74 & 11.31 \\
\hline
\end{tabular}

Table 1 shows that male students performed better than their female counterparts in periodic tests and terminal examination, male students recorded high mean scores in mathematics periodic tests and terminal examination than their female counterparts. This implies that there is gender disparity in the academic performance of students in mathematics periodic tests and terminal examination.

\section{Hypothesis 1}

There is no significant difference between the academic performance of male and female students in mathematic periodic tests and terminal examination.

Table 2: t-test analysis of students' academic performance in mathematics periodic tests and terminal examination by gender.

\begin{tabular}{|c|c|c|c|c|c|c|c|}
\hline $\begin{array}{l}\text { Academic } \\
\text { Performance }\end{array}$ & Gender & $\mathrm{N}$ & Mean & SD & df & $\mathrm{T}$ & $\mathrm{p}$ \\
\hline Test 1 & $\begin{array}{l}\text { Male } \\
\text { Female }\end{array}$ & $\begin{array}{l}100 \\
100\end{array}$ & $\begin{array}{l}5.02 \\
4.46\end{array}$ & $\begin{array}{l}1.13 \\
1.21\end{array}$ & 198 & $3.386^{*}$ & 0.001 \\
\hline Test 2 & $\begin{array}{l}\text { Male } \\
\text { Female }\end{array}$ & $\begin{array}{l}100 \\
100\end{array}$ & $\begin{array}{l}5.00 \\
4.56 \\
\end{array}$ & $\begin{array}{l}1.19 \\
1.35 \\
\end{array}$ & 198 & $2.445^{*}$ & 0.015 \\
\hline Test 3 & $\begin{array}{l}\text { Male } \\
\text { Female }\end{array}$ & $\begin{array}{l}100 \\
100\end{array}$ & $\begin{array}{l}4.98 \\
4.58\end{array}$ & $\begin{array}{l}1.26 \\
1.29\end{array}$ & 198 & $2.217^{*}$ & 0.028 \\
\hline Test 4 & $\begin{array}{l}\text { Male } \\
\text { Female }\end{array}$ & $\begin{array}{l}100 \\
100\end{array}$ & $\begin{array}{c}4.88 \\
4.40\end{array}$ & $\begin{array}{l}1.33 \\
1.22 \\
\end{array}$ & 198 & 2.569 & 0.008 \\
\hline Examination & $\begin{array}{l}\text { Male } \\
\text { Female }\end{array}$ & $\begin{array}{l}100 \\
100\end{array}$ & $\begin{array}{c}53.98 \\
47.74\end{array}$ & $\begin{array}{l}11.96 \\
11.31\end{array}$ & 198 & $3.791^{*}$ & 0.000 \\
\hline
\end{tabular}

$* \mathrm{P}<0.05$

Table 2 showed that there was significant difference between the academic performance of male and female students in mathematics periodic Test $1(\mathrm{t}=3.386, \mathrm{P}<0.05)$, Test $2(\mathrm{t}=2.445, \mathrm{P}<0.05)$, Test $3(\mathrm{t}=2.217, \mathrm{P}<$ $0.05)$, Test $4(\mathrm{t}=2.659, \mathrm{P}<0.05)$ and Terminal examination $(\mathrm{t}=3.791, \mathrm{P}<0.05)$ at 0.05 level of significance. Thus, the null hypothesis was rejected.

\section{HYPOTHESIS 2}

There is no significant gender difference in the contribution of students' performance in mathematics Periodic Tests to their academic performance in Terminal Examination in Mathematics.

Table 3: Multiple Regression analysis of Mathematics Periodic Tests as Predictors of students' performance in Mathematics Terminal Examination by gender.

\begin{tabular}{|c|c|c|c|c|c|c|c|c|c|}
\hline Gender & Model & B & $\begin{array}{l}\text { Std } \\
\text { Error }\end{array}$ & Beta & $\mathrm{t}$ & Sig.T & $\mathrm{R}$ & $\mathrm{R}^{2}$ & $\mathrm{~F}$ \\
\hline \multirow{5}{*}{ Male } & Constant & -.354 & 1.883 & & -.188 & .851 & \multirow{5}{*}{.957} & \multirow{5}{*}{.916} & \multirow{5}{*}{$258.574^{*}$} \\
\hline & Test 1 & 4.381 & .381 & .413 & 11.492 & .000 & & & \\
\hline & Test 2 & 1.217 & .532 & .121 & 2.288 & .024 & & & \\
\hline & Test 3 & .867 & .615 & .092 & 1.409 & .162 & & & \\
\hline & Test 4 & 4.496 & .733 & .499 & 6.130 & .000 & & & \\
\hline \multirow{5}{*}{ Female } & Constant & 1.082 & 1.879 & & .576 & .566 & \multirow{5}{*}{.936} & \multirow{5}{*}{.875} & \multirow{5}{*}{$166.603^{*}$} \\
\hline & Test 1 & 3.057 & .389 & .327 & 7.864 & .000 & & & \\
\hline & Test 2 & 3.584 & .506 & .428 & 7.090 & .000 & & & \\
\hline & Test 3 & 3.347 & .461 & .381 & 7.252 & .000 & & & \\
\hline & Test 4 & .307 & .665 & .033 & .462 & .645 & & & \\
\hline
\end{tabular}

Table 3 shows that the four Mathematics Periodic Tests made a significant contribution to the performance 
of male and female students in Terminal Examination in mathematics. From analysis of variance of the regression data, F-value of 258.574 (male) and 166.603 (female) significant $\mathrm{p}<0.05$ were obtained.

The four Periodic Tests were better predictor of academic performance of male students $\left(\mathrm{R}^{2}=0.916\right)$ in Mathematics Terminal Examination than their female counterparts $\left(\mathrm{R}^{2}=0.875\right)$. Therefore, the null hypothesis was rejected. Consequently, there is a significant gender difference in the contribution of students' performance in Periodic Tests to their academic performance in Terminal Examination in mathematics.

\section{Discussion}

The result of the study indicates that male students performed better than their female counterpart in mathematics. Also, the result shows that there is gender difference in the contribution of students' performance in periodic tests to their academic performance in terminal examination in mathematics. The result of the study agrees with the findings of Smith \& Walker (1988), Popoola \& Ajani (2000) and Oloda (2017) that male students perform better than female students in mathematics. Also, the result is not in agreement with the findings of Olusunde and Oghodo (2015) that there is no significant difference between male and female students' achievement in mathematics.

\section{Conclusion}

Periodic tests and terminal examination are systematic process used by teachers to determine how well the instructional objectives have been achieved. They are continuous assessment strategies implemented by teachers to ascertain the knowledge, understanding and skills attained by students. This study had established that students' performance in mathematics periodic tests and terminal examination were affected by students' gender.

\section{Recommendations}

Based on the findings in this study, it was recommended that:

Teachers should be gender sensitive and accommodating by putting into consideration individual differences in the students' rate of learning irrespective of gender.

\section{References}

Adetula, L.O (2010) Mathematics: A cognitive tool for national development building. In S.O Ale and Adetula L.O (Eds), Reflective and Intellective position papers on mathematics Education. Abuja. Marvelous Press.

Agwagah, U (2013). Improving the teaching of mathematics for attainment of seven point agenda: Implication for gender parity. Abacus, The Journal of the Mathematical Association of Nigeria. 38(1) 111-121

Ajayi, O.B \& Ighoroje A.D (2000). Female enrolment for information technology training in Nigeria. Available online at www.wigsat.org. Retrieved on 07/02/2015.

Cronbach L.J (1997). Educational Psychology. Harcourt Braice, Javanovich Inc, USA.

Faleye, B.A \& Dibu-Ojerinde, O. O (2006). A review of the enrolment and performance of male and female students in education economics programme, Obafemi Awolowo University, Ile-Ife. Journal of Social Science, 12 (2), 143-146.

Jahun, I.U (1989). Construction and standardization of mathematics achievement test for junior secondary school three students in Kaduna and Katsina State of Nigeria. Abacus, the Journal of the Mathematical Association of Nigeria 24(1), 30-32.

Jahun, I.U. and Momoh, J.S. (2001): The Effect of Environment and Sex on the Mathematics Achievement of Senior Secondary School Three Students in Kwara State. ABACUS. Journal of the Mathematical Association of Nigeria. Vol. 26, Issue 1, pp. 53-58

Korau, Y.K (2006). A systematic attempt to establish the fear and poor performance of senior secondary school students in Geometry and trigonometric concepts: A case study of WAEC Candidates. A paper presented at the $43^{\text {rd }}$ Annual conference of the Mathematical Association of Nigeria held at A.T.B.U Bauchi.

National Policy of Education (2004): Federal Republic of Nigeria, Lagos NERC Press.

Oloda, F.S.S \& Adebule S.O. (2017). Differential item functioning of test items of 2014 Joint senior secondary II mathematics promotion examination in Ondo State, Nigeria. EKSOJOE Journal of education 7(3), 40-47

Oloda F.S. Smart (2017) Gender, Environment and Parents' Socio-Economic Status as Determinant of Students Performance in Mathematics Periodic Tests and Terminal Examination in Ondo State Secondary Schools. ABACUS the Journal of Mathematical Association of Nigeria, 42 (1), 229-237.

Oloda, F. S., \& Awogbemi, C. A. (2012). Self assessment in mathematics as correlate of Performance of Students in physics. Journal of Research in National Development, (JORIND), FUTO. 10(2), 46-49.

Olosunde, G.R \& Ogbodo, C.N. (2015) Impact of school location, students' motivation on attitude and achievement in mathematics. A paper presented at the $52^{\text {nd }}$ Annual conference of the Mathematical Association of Nigeria held at Enugu between $30^{\text {th }}$ August $-4^{\text {th }}$ September, 2015.

Popoola, B.A \& Ajani, T.O (2011). Influence of pupils' gender, environment and school ownership status on 
mathematics performance of secondary school students in Yewa North, Ogun State. Abacus Journal of Mathematical Association of Nigeria, 36(1), 56-65.

Smith, S.E \& Walker, W.J (1988). Sex differences in New York State Regents Examination: Support for the differential course-taking hypothesis. Journal of Research in Mathematics Education, 19(1), 81-84.

Yoloye, E.A (1984) Continuous Assessment: A Guide for Teachers. Cassell Ltd. London. 